\title{
PENERAPAN METODE CTL (CONTEXSTUAL TEACHING AND \\ LEARNING) UNTUK MENINGKATKAN MOTIVASI DAN HASIL \\ BELAJAR BIOLOGI SISWA KELAS XI IPA.1 SMA NEGERI \\ JENGGAWAH
}

MELALUI PEMBUATAN MODEL STRUKTUR SEL 3D

\author{
An Rini Mudayanti, S.Pd ${ }^{1}$ \\ Guru SMAN 1 Jenggawah, Jember \\ Email : anrinirini@gmail.com
}

\begin{abstract}
Abstrak : The research application of CTL (contextual teaching and learning) method through making of 3D cell model aims to determine the effect on student's motivation, learning outcomes and to find out the understanding student concepts. For this reason, it is necessary to have a PTK with 2 cycles. The subjects of this research were students of SMA Negeri Jenggawah especially class XI IPA.1 which consisted of 36 students with 12 male and 24 female. The data analysis used is standards descriptive statistical of data analysis. The results of this research indicate that the application of CTL method through making of 3D cell models has a significant impact on student motivation and learning outcomes. Indicated by an increase in student learning motivation, so that it affects learning outcomes from pre-cycle to cycle 2 by $69 \%$. There were 25 students who obtained very good criteria and an increase in classical learning outcomes of $86.11 \%$ (31 students who completed) with an average score of $79.83=80$ and the highest score was 98 while the lowest score was 68 .
\end{abstract}

Keywords: Motivation, Learning Outcomes, Contexstual Teaching And Learning, 3D Model. 


\section{PENDAHULUAN}

Pembelajaran di dunia pendidikan berperan penting dalam membentuk dan menciptakan peserta didik yang berkualitas. Pada abad 21 sistem pendidikan nasional mengahadapi tantangan yang sangat kompleks, upaya yang paling tepat dalam menyiapkan SDM yang berkualitas melalui pendidikan. Hal ini selaras dengan Undang-Undang No 20 tahun 2003 tentang sistem Pendidikan Nasional, dimana pendidikan adalah usaha sadar dan terencana untuk mewujudkan suasana belajar dan proses pembelajaran agar siswa secara aktif mengembangkan potensi dirinya untuk memiliki kekuatan spiritual keagamaan, pengendalian diri, kepribadian, kecerdasan, berakhlak mulia, cakap, kreatif, mandiri, trampil, dan menjadi warga negara yang demokratis serta bertanggungjawab yang diperlukan untuk dirinya, masyarakat, bangsa dan negara.

Selain itu pembelajaran harus direncakan dari dua dimensi kegiatan yaitu belajar dan mengajar, yang mengarah pada suatu tujuan. Pada dasarnya pembelajaran yang terencana itu dapat merangsang atau mengkondisikan peserta didik agar bisa belajar dengan baik secara optimal. Menurut Tampubolon : 2013, bahwa pendidikan adalah proses yang tanpa akhir (education is the proses without end), dan pendidikan merupakan proses pembentukan kemampuan dasar yang fundamental baik menyangkut daya pikir, daya intelektual maupun emosional/perasaan yang diarahkan kepada tabiat manusia dan kepada sesamanya.

Biologi merupakan bagian sains, yang memiliki peran penting dalam meningkatkan mutu pendidikan memalui kemampuan berfikir kritis bagi siswa untuk bekal masa depan mereka, Selain itu dalam pembelajaran biologi terdapat tiga aspek yang menjadi dasar sains yaitu proses, produk, dan sikap. Ketiga aspektersebut menjadi karakteristik yang ada dalam pembelajaran biologi Hal ini yang menuntut diperlukan inovasi metode pembelajaran agar dapat lebih efektif dan menyenangkan,sehingga dalam proses pembelajaran guru mempunyai peranan yang sangat penting agar siswa aktif dalam proses pembeajaran dan 
memperoleh prestasi atau hasil belajar yang memuaskan, hal ini tak lepas dari motivasi yang dimiliki oleh peserta didik.

Hal ini dapat dilihat dari hasil angket motivasi belajar yang disebar pada tanggal 16 Juli 2019 diperoleh rincian sebagai berikut : kriteria sangat tinggi (ST) $0 \%$ atau 0 siswa, pada kreteria tinggi ( $\mathrm{T}$ ) berkisar $55 \%$ (20 siswa), pada kreteria cukup berkisar 34\% (12 siswa), pada kreteria rendah (R) berkisar 11\% (4 siswa) dan pada kreteria sangat rendah (SR) berkisar 0\% (0 siswa). Begitu juga dengan hasil ulangan belajar pesera didik pada pokok bahasan Sel (Sturktur dan fungsi komponen organel penyusun sel) yang dilakukan pada tanggal 30 Juli 2019 diperoleh hasil sebagai berikut : Hasil belajar yang dicapai dari 36 siswa, 8\% memperoleh kriteria sangat baik (SB) berkisar 3 siswa , kreteria baik (B) berkisar 33\% (12 siswa), kreteria cukup baik (CB) berkisar 28\% (10 siswa), kreteria kurang baik (KB) berkisar 19\% (7 siswa) dan kreteria sangat kurang baik (SKB) berkisar 11\% (4 siswa). Data tersebut diperoleh dari hasil observasi dan data perolehan hasil belajar siswa pada pokok bahasan KD 3.1 tentang sel.

Fokus permasalahan dari rendahnya motivasi dan hasil belajar siswa disebabkan pembelajaran masih sekedar memaparkan fakta, pengetahuan masih biasa dihafalkan (textual) dan pemahaman konsep materi sel cenderung masih kurang, sehingga dalam proses pembelajaran siswa terlihat pasif, kurang komunikatif dan tidak konsentrasi/kurang fokus. kurangnya pemaham konsep serta pengetahuan yang didapat hanya ada pada tahapan "hafalan" hal ini mengakibatkan materi yang didapat mudah terlupakan. Fakor yang lainnya dikarenakan peserta didik kurang aktif dalam bertanya pada saat guru menjelaskan atau pada saat diskusi berlangsung peserta didik tidak memiliki keberani untuk mengutarakan pendapat dan mengajukan pertanyaan, selain itu sebagian besar peserta didik tidak dapat menyelesaikan soal ulangan dengan baik.

Adapun alternatif untuk pemecahan permasalahan diatas :

1. Dengan menggunakan metode CTL (Contextual Teaching and Learning), dengan metode CTL siswa akan lebih aktif dan lebih berkonsentrasi dalam proses pembelajaran di kelas, peserta didik juga akan terlibat langsung dalam 
penguasaan materi dan pemahaman konsep terhadap materi yang diajarkan, sehingga peserta didik dapat membangun pengetahuannya secara mandiri.

2. Melibatkan peserta didik dalam pembuatan alat peraga/model pembelajaran yang relevan dengan materi, pembuatan model sel 3D digunakan untuk mengetahui kreativitas siswa sekaligus memberikan pembelajaran yang bermakna bagi siswa.

Pembelajaran yang baik adalah suatu proses belajar mengajar dimana kegiatan tersebut berpusat pada siswa (student center). Belajar akan lebih bermakna jika anak mengalami apa yang dipelajarinya, bukan mengetahuinya. Pembelajaran yang berorientasi pada penguasaan materi terbukti berhasil dalam kompetisi mengingat jangka pendek, akan tetapi gagal dalam membekali anak memecahkan persoalan dalam kehidupan jangka panjang.

Belajar yang bermakna dapat memudahkan siswa untuk mengingat informasi yang ia pelajari lebih lama, maksud dari belajar bermakna dalam proses pembuatan model sel 3D adalah siswa mengalami apa yang sedang ia pelajari. Selain itu pembuatan model sel 3D merupakan masalah yang harus dipecahkan siswa secara kreatif dan dalam proses berpikir kreatifnya siswa perlu memiliki pengetahuan tentang sel itu sendiri. Sehingga konsep terhadap struktur dan fungsi komponen organel - organel sel lebih cepat dipahami peserta didik. Metode CTL akan lebih efektif jika di padukan dengan penggunaan alat peraga, dimana siswa berkontribusi dan terkontruksi untuk membuat model sel 3D.

\section{METODE PENELITIAN}

Penelitian dilaksankan di SMAN Jenggawah, Kabupaten Jember beralamat di Jalan Tempurejo No.76 Jenggawah - Jember, pada semester ganjil tahun pelajaran 2019/2020 selama 3 bulan dimulai pada akhir bulan Juli - Oktober 2019 sebanyak dua siklus, dimana pada setiap siklusnya ada dua kali tatap muka. Subjek dalam penelitian ini adalah siswa kelas XI.IPA-I SMAN Jenggawah berjumlah 36 siswa dengan 12 siswa laki-laki dan 24.

Penelitian dilaksanakan dengan dua siklus, dimana pada setiap siklus terdiri dari 2 pertemuan, dimana penelitian mengabdopsi dari Kemis dan Mc Taggart dalam Herawati, (2009:12). Model penelitian tindakan kelas terdiri dari 
empat tahap yaitu perencanaan, tindakan, observasi dan refleksi. Adapun alur pelaksanaan penelitian meliputi:

a) Perencanaan (Planning)

Perencanaan selalu mengacu kepada tindakan apa yang dilakukan, dengan mempertimbangkan keadaan, seperti perlu dipertimbangkan tindakan khusus apa yang akan dilakukan dan apa tujuannya (Setyosari, 2013 ).

b) Pelaksanaan Tindakan / Acting

Adapun kegiatan yang dilakukan dalam pelaksanaan tindakan ini adalah sebagai berikut :

\section{Langkah-langkah}

(1)

\section{Kegiatan Guru}

(2)
Kegiatan Siswa

(3)

1. Kegiatan Awal

a. Menyampaikan topik

b. Menyampaikan tujuan, memotivasi pembelajaran.

\section{Menuliskan topik pembelajaran}

di papan tulis/PPT

Menyampaikan tujuan dan

memotivasi siswa

2. Kegiatan Inti

a. Kontruktivisme

b. Inquir

c. Bertanya

\section{Menjabarkan materi dan membagi kelompok berdasarkan heterogenitas}

Memberikan LKPD tentang segmen materi yang dibahas dan membimbing siswa dalam menemukan informasi.

Guru mengajukan pertanyaan tentang informasi yang sudah digali atau ditemukan

\section{Mendengarkan informasi}

yang disampaikan guru

Menyimak informasi dan

tujuan belajar yang

disampaikan guru

\begin{abstract}
Menyimak informasi materi secara umum yang akan dipelajari dan duduk berdasarkan kelompok yg sudah dibentuk.

Menerima dan membaca LKPD yg diberikan guru. mencari informasi terkait dengan materi yg diamati.

Siswa saling berdiskusi untuk menjawab pertanyan dari guru
\end{abstract}


d. Masyarakat

Belajar

f. Refleksi

g. Penilaian

Otentik
Guru membantu setiap kelom-

pok agar dapat melakukan

transmisi secara efesien, guru

juga membimbing kelompok

belajar untuk melakukan prak-

tikum sesuai dengan petunjuk

LKPD, membuat laporan dan

membuat bahan presentasi ber-

dasarkan laporan yang dibuat

Guru membimbing siswa utk mempresentasikan hasil kerja

kelompok didepan kelas guna

memberikan informasi lebih

lanjut tentang materi yang

sedang dipelajari.

Merefleksikan hasil diskusi kls

dan mengoreksi hasil pekerjaan

tiap kelompok, memberikan info

lebih lanjut terkait materi yang

dipelajari, mberikan pesan moral

dan meminta siswa utk mencatan

hasil diskusi.

Melakukan evaluasi proses

diskusi dengan memberikan

penguatan pada diskusi kelas

Guru mengevaluasi hasil pem-

belajaran dengan memberikan

Tes berupa soal tertulis
Siswa secara aktif dan

bekerja sama dengan

kelompoknya untuk

mengerjakan LKPD

Dengan petunjuk guru

siswa melakukan diskus

kelas yg diwakili oleh

beberapa kelompok

(setiap jubir kelompok

mempresentasikan hasil

diskusi kelompok.

Mengoreksi hasil LKPD

yg dihasilkan oleh teman

dan menyimak informasi

dari guru

Menyimak evaluasi dan penjelasan guru.

Siswa mengerjakan soal

tes

3. Penutup

Membimbing siswa membuat

kesimpulan dan memberikan

tugas untuk mempelajari materi

Pertemuan yang akan datang.
Menyimak penjelasan

yang disampaikan oleh

guru. 


\section{c) Observasi}

Observasi dilakukan untuk pengamatan terhadap proses belajar siswa. Adapun fungsi dilakukannya observasi adalah untuk mengetahui sejauh mana perhatian dan aktivitas proses belajar siswa dalam kegiatan pembelajaran.

d) Refleksi (Reflecting)

Refleksi adalah suatu upaya untuk mengkaji apa yang telah terjadi, yang telah dihasilkan, atau apa yang belum dihasilkan, atau apa yang belum tuntas dari langkah atau upaya yang telah dilakukan (Setyosari, 2014).

Tehnik pengumpulan data pada penelitian ini menggunakan metode tes (tes tertulis) dan non tes ( observasi, angket motivasi ARCS by Keller (adaptasi dari Basit, A. 2011:105) dan dokumentasi ). Dalam penelitian ini menggunakan analisis data statistik deskriptif dengan patokan atau standar. Dikatakan patokan, sebab sebelum dilakukan penelitian patokan tersebut telah ditetapkan sebelumnya. Adapun analisis ini meliputi :

a). Hasil Belajar Siswa

Pengklasifikasian hasil belajar siswa setelah dilakukan pengukuran hasil belajar, maka digunakanlah lima kriteria: sangat baik, baik, kurang. Rentangan skor untuk setiap klasifikasi hasil belajar tersebut dapat diikuti kriteria di bawah ini.

Tabel 1 Patokan Kreteria Hasil Belajar Siswa

\begin{tabular}{|l|l|}
\hline Kriteria Hasil Belajar & Rentangan Skor \\
\hline Sangat Baik & $80-100$ \\
\hline Baik & $70-79$ \\
\hline Sedang/Cukup Baik & $60-69$ \\
\hline Kurang Baik & $40-59$ \\
\hline Sangat kurang Baik & $0-39$ \\
\hline ( Diadaptasi dari Masyud, M. Sulton.2012:66). \\
b). Motivasi Belajar
\end{tabular}


Data kualitatif berupa hasil angket motivasi belajar siswa dianalisis dengan menggunakan rumus sebagai berikut :

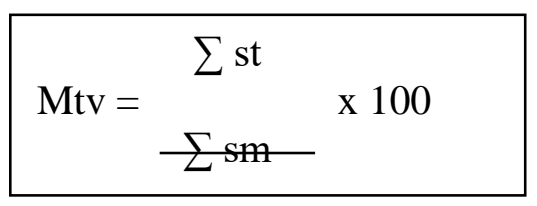

Keterangan :

Mtv = motivas

$\sum$ st $=$ Jumlah skor tercapai

$\sum \mathrm{sm}=$ Jumlah skor maksimal yang

bisa dicapai.

( Diadaptasi dari Masyud, M.Sulton. 2014:34)

Berdasarkan hasil penilaian dengan skala 100, kemudian ditafsirkan dengan rentang kualitatif seperti yang terlihat pada tabel 2 di bawah ini:

Tabel. 2. Patokan Kreteria Motivasi Belajar Siswa

\begin{tabular}{|l|l|}
\hline Kriteria Motivasi Belajar & Rentangan Skor \\
\hline Sangat Tinggi & $81-100$ \\
\hline Tinggi & $61-80$ \\
\hline Cukup & $41-60$ \\
\hline Rendah & $21-40$ \\
\hline Sangat Rendah & $0-20$ \\
\hline
\end{tabular}

( Diadaptasi dari Masyud, M. Sulton. 2012:71)

\section{HASIL PENELITIAN DAN PEMBAHASAN}

Data utama pada penelitian ini ada 2 yaitu data hasil belajar siswa dan data motivasi belajar siswa. Penyajian hasil penelitian ini diawali tentang data hasil belajar siswa pada pra siklus, siklus 1 dan siklus 2. Data hasil belajar dalam penelitian ini adalah skor hasil tes tertulis yang mencakup materi pokok bahasan Sel bab materi teori perkembangan sel dan komponen kimia sel untuk pra siklus, pengertian struktur sel prokariotik dan eukariotik, membran sel, sitoplasma, dan organel-organel sel untuk siklus 1, sedangkan siklus ke 2 dengan materi struktur dan fungsi sel yaitu materi tentang organel-organel sel.

1. Pra Siklus, merupakan kegiatan pembelajaran sebelum diterapkan metode CTL

2. Siklus 1 dan Siklus 2, merupakan kegiatan pembelajaran setelah diterapkan metode CTL 
Sedangkan data kondisi hasil belajar siswa pada Pra Siklus, Siklus 1, dan Siklus 2 tercantum pada Tabel 4 berikut ini :

Tabel 4. Peningkatan hasil belajar kognitif siswa secara klasikal

\begin{tabular}{lllllll}
\hline \multirow{2}{*}{ No } & \multicolumn{2}{l}{ Skor Nilai Tes Tertulis } & & & \\
\cline { 2 - 7 } & Pra & Siklus & Siklus & Peningkatan & Peningkatan & Peningkatan \\
\cline { 2 - 7 } & Siklus & 1 & 2 & $\begin{array}{l}\text { Pra siklus ke } \\
\text { siklus } 1\end{array}$ & $\begin{array}{l}\text { Siklus } 1 \\
\text { siklus } 2\end{array}$ & $\begin{array}{l}\text { Pra } \\
\text { siklus } 2\end{array}$ \\
\hline Total & 2352 & 2635 & 2874 & 283 & 239 & 522 \\
\hline Rerata & 65 & 73 & 80 & 8 & 7 & 15 \\
\hline Tertinggi & 85 & 89 & 98 & 23 & 35 & 45 \\
\hline Terendah & 25 & 35 & 68 & 4 & -1 & -2 \\
\hline
\end{tabular}

Berdasarkan tabel 4. terdapat peningkatan hasil belajar siswa pada setiap siklusnya. Peningkatan rerata hasil belajar siswa dari prasiklus ke siklus 1 sebesar $8 \%$, dimana jumlah rerata untuk prasiklus sebesar 65 dan pada siklus 1 sebesar 73 dan peningkatan rerata hasil belajar siswa pada siklus 1 ke siklus 2 juga terjadi peningkatan sebesar 7\% dengan skor rerata pada siklus 2 sebesar 80 . Sedangkan peningkatan rerata hasil belajar siswa pada pra siklus ke siklus 2 mengalami peningkatan $15 \%$. Sehingga peningkatan ketuntasan hasil belajar siswa dari pra siklus hingga pasca siklus secara berurutan dapat dilihat dari skor siswa yang memiliki nilai 75 keatas atau berdasarkan KKM yang sudah ditetapkan adalah 15 siswa atau 41,67\% pada pra siklus, 23 siswa atau 63,89\% pada siklus 1 dan 31 siswa atau $86,11 \%$ pada siklus 2 .

Sedangkan data kondisi hasil belajar siswa pada Pra Siklus, Siklus 1, dan Siklus 2 tercantum pada Tabel 5 berikut ini :

Tabel 5. Kondisi Hasil Belajar Siswa Pada PraSiklus, Siklus 1 dan Siklus 2

\begin{tabular}{llllllll}
\hline Kategori Hasil & Rentangan & \multicolumn{2}{l}{ Kondisi Hasil Belajar } & & \\
\hline Belajar & Skor & \multicolumn{2}{l}{ Pra Siklus } & \multicolumn{2}{l}{ Siklus 1 } & \multicolumn{2}{l}{ Siklus 2 } \\
\hline & & F & \% & F & \% & F & \% \\
\hline Sangat Baik & $80-100$ & 3 & 8 & 13 & 36 & 25 & 69 \\
\hline Baik & $70-79$ & 12 & 33 & 15 & 42 & 10 & 28 \\
\hline Cukup Baik & $60-69$ & 10 & 28 & 5 & 14 & 1 & 3 \\
\hline Kurang Baik & $40-59$ & 7 & 20 & 1 & 3 & 0 & 0 \\
\hline Sangat Kurang Baik & $0-39$ & 4 & 11 & 2 & 5 & 0 & 0 \\
\hline Jumlah & & 36 & 100 & 36 & 100 & 36 & 100 \\
\hline
\end{tabular}


Berdasarkan data diatas kondisi hasil belajar siswa pada prasiklus dimana belum ada perlakuan dalam metode pembelajarannya, sehingga hasil sangat baik hanya 8\% sama dengan 3 siswa, katagori baik 33\% (12 siswa) katagori cukup baik $28 \%$ (10 siswa) untuk katagori kurang baik 20\% yaitu 7 siswa sedangkan katagori sangat kurang baik $11 \%$ sebanyak 4 siswa.

Kemudian pada siklus 1 hasil belajar siswa sudah mengalami peningkatan pada setiap katagorinya, untuk katagori sangat baik menjadi 36\% (13 siswa), katagori baik bekisar 42\% (15 siswa), untuk katagori cukup baik, kurang baik dan sangat kurang baik mengalami penurunan sebesar 14\% (5 siswa), kurang baik 3\% (1 siswa) dan sangat kurang baik sebesar 5\% (2 siswa) hal ini sejalan dengan peningkatan pada katagori baik dan sangat baik.

Pada siklus 2 secara berurutan katagori sangat baik dan baik mengalami peningkatan sebesar 69\% (25 siswa) dan $28 \%$ (10 siswa) hal ini berkaitan dengan pengurangan pada katagori cukup baik, kurang baik dan sangat kurang baik yang mengalami penurunan, sehingga persentase dari masing-masing katagori secara berurutan menjadi sebesar 3\% (1 siswa) untuk katagori cukup baik, 0\% (0 siswa) untuk kurang baik dan sangat kurang baik.

Adapun persentase peningkatan hasil belajar siswa secara klasikal dapat dilihat dari gambar diagram di bawah ini

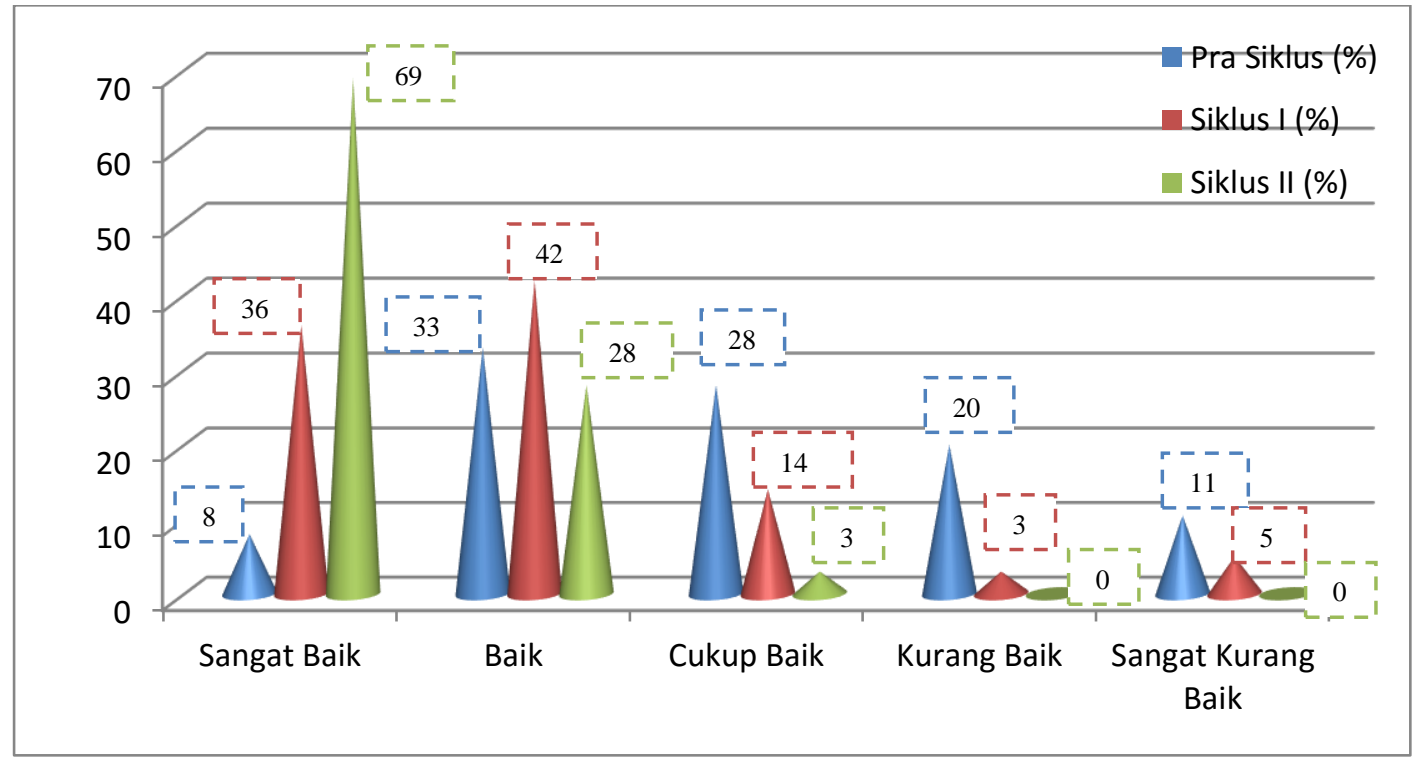

Gambar Histogram 1. Perbandingan Hasil Belajar Siswa Pada Pra Siklus, Siklus 1 dan Siklus II Berdasarkan 5 Klasifikasi Penilaian. 
belajar siswa dari Pra Siklus ke Siklus 1 dan Siklus 1 ke Siklus 2. Hasil tersebut memungkinkan untuk tidak melanjutkan ke siklus berikutnya karena hasil belajar siswa dengan kategori cukup baik, kurang baik dan sangat kurang baik sudah tidak ada.

Data utama kedua adalah data motivasi belajar siswa, data tersebut diperoleh dari pengisian angket motivasi. Selanjutnya data persenase perbandingan rata-rata aspek motivasi belajar siswa pada Pra Siklus, Siklus 1, dan Siklus 2 terdapat dalam tabel 6 sebagai berikut.

Tabel 6. Persentase peningkatan motivasi hasil belajar

\begin{tabular}{|c|c|c|c|c|c|c|}
\hline \multirow{2}{*}{ Perlakuan } & \multicolumn{4}{|c|}{$\sum$ Indikator motivasi hasil belajar } & \multirow{2}{*}{$\begin{array}{r}\sum \text { Aspek } \\
\text { Motivasi }\end{array}$} & \multirow{2}{*}{$\begin{array}{l}\text { Rerata } \\
\text { Kelas }\end{array}$} \\
\hline & Attention & Relevance & Confidence & Satisfaction & & \\
\hline Pra Siklus & 28,44 & 31,18 & 16,72 & 17,94 & 94,92 & 63 \\
\hline Siklus 1 & 34,28 & 41,22 & 18,64 & 20,17 & 114,31 & 76 \\
\hline Siklus 2 & 41,50 & 48,89 & 18,75 & 20,86 & 130,00 & 87 \\
\hline $\begin{array}{l}\text { Peningkatan } \\
\text { Pra siklus ke } \\
\text { siklus } 1\end{array}$ & 5,84 & 10,04 & 1,92 & 2,92 & 19,39 & 13 \\
\hline Peningkatan & & & & & & \\
\hline $\begin{array}{lll}\text { siklus } & 1 & \text { ke } \\
\text { siklus } 2 & & \end{array}$ & 7,22 & 7,67 & 0,11 & 0,69 & 15,69 & 11 \\
\hline
\end{tabular}

Dari tabel diatas diperoleh nilai motivasi yang terdiri dari empat aspek mengalami peningkatan yang sangat signifikan dari pra siklus, siklus 1 ke siklus 2, dimana pada nilai rerata motivasi pra siklus ke siklus 1 mengalami peningkatan $13 \%$ dari nilai $63 \%$ menjadi $76 \%$, begitu juga nilai rerata hasil motivasi pada siklus 1 ke siklus 2 mengalami peningkatan $11 \%$ dari $76 \%$ pada siklus 1 menjadi $87 \%$ pada siklus 2 .

Pada tabel 6. secara rinci menunjukan bahwa setiap indikator motivasi hasil belajar siswa mengalami peningkatan disetiap siklusnya. Untuk aspek perhatian (Attention) pada prasiklus diperoleh angka 28,44\% kemudian meningkat menjadi $34,28 \%$ pada siklus 1 dan pada siklus 2 meningkat menjadi $41,50 \%$, sedangkan perbandingan persentase peningkatan dari prasiklus ke siklus 1 sebesar 5,84\% dan pada siklus 1 ke sikus 2 mengaami peningkatan 7,22\%. 
Peningkatan pada aspek relevansi (Relevance) sebesar 31,18 pada prasikus dan meningkat pada siklus 1 dengan perolehan 41,22\%, sedangkan pada siklus 2 peningkatannya sebesar $48,89 \%$. Untuk peningkatan perbandingan persentase dari prasiklus ke siklus 1 meningkat 10,04\% dan pada siklus 1 ke siklus 2 menjadi 7,67\%. Pada prasiklus untuk aspek kepercayaan (Confidance) mengalami peningkatan $16,72 \%$, untuk siklus 1 dan 2 secara berurutan peningkatanya menjadi $18,64 \%$ dan $18,75 \%$.

Adapun perbandingan persentase peningkatan dari prasiklus ke siklus 1 sebesar $1,92 \%$ dan pada siklus 1 ke siklus 2 peningkatannya menjadi $0,11 \%$. Sedangkan pada aspek kepuasan (satisfaction) peningkatan pada prasiklus sebesar $17,94 \%$, sedangkan pada siklus 1 meningkat menjadi 20,17\%, kemudian meningkat menjadi $20,86 \%$ pada siklus 2 . Untuk peningkatan dari prasiklus ke siklus 1 perbandingan persentasenya sebesar $2,92 \%$ dan pada siklus 1 ke siklus 2 persentasenya meningkat sebesar $0,69 \%$.

Sedangkan peningkatan motivasi belajar siswa dari prasiklus, siklus 1 dan siklus 2 berdasarkan rentang kualitatif patokan kriteria motivasi belajar dapat dilihat pada tabel 7 sebagai berikut.

Tabel 7 Persentase peningkatan motivasi belajar secara klasikal

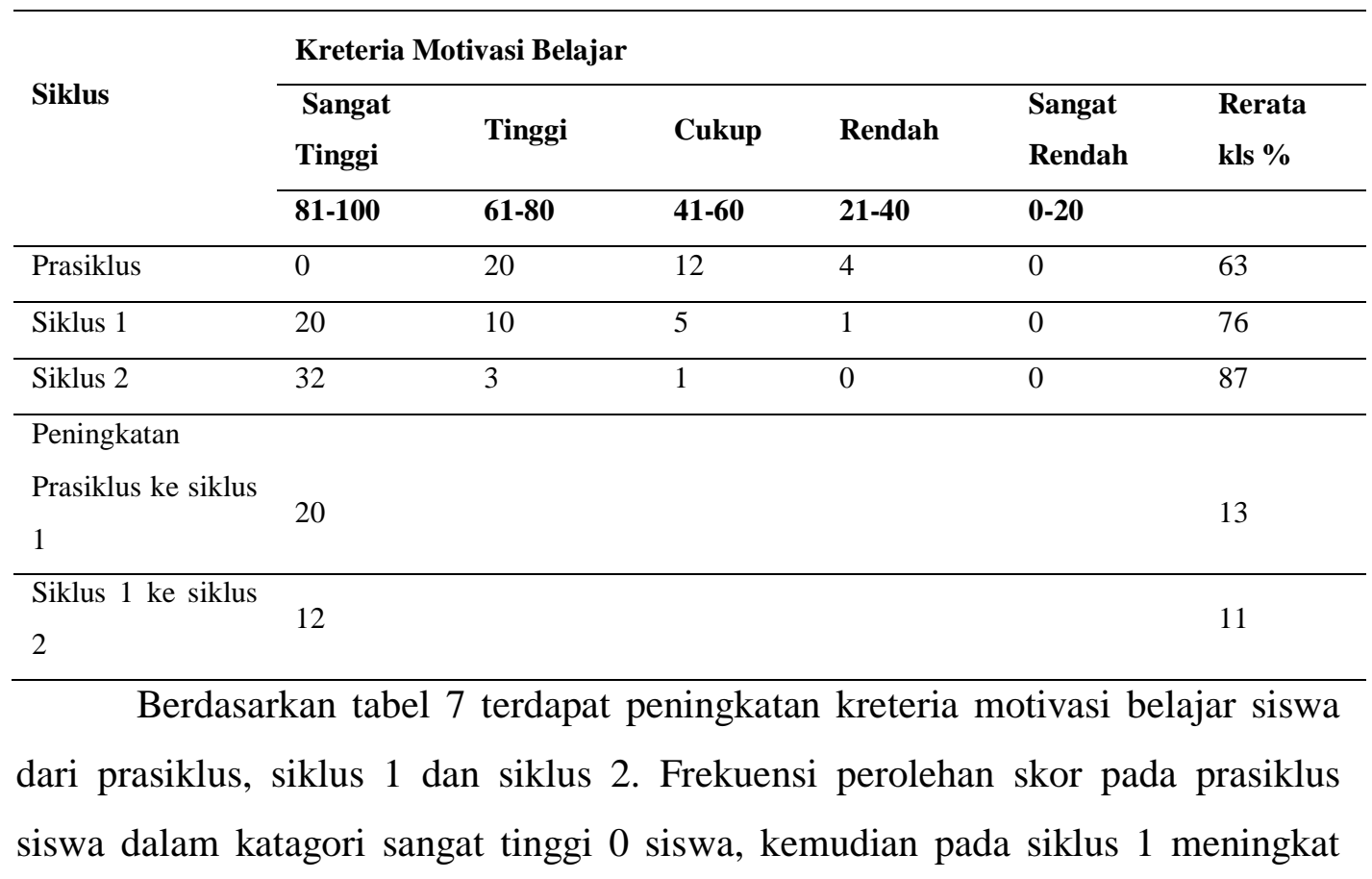


menjadi 20 siswa dan pada siklus 2 meningkat menjadi sebanyak 32 siswa. Untuk jumlah siswa dalam katagori tinggi pada prasiklus sebanyak 20 siswa dan pada siklus 1 menjadi 10 siswa, kemudian pada siklus 2 mengalami penurunan menjadi 3 siswa, hal ini seiring dengan peningkatan skor yang diperoleh dalam katagori sangat tinggi.

Dilihat dari rerata kelas pada prasiklus sebesar $63 \%$ yaitu tergolong cukup, sedangkan rerata kelas pada siklus 1 sebesar $76 \%$ tergolong baik, sehingga terdapat peningkatan dari prasiklus ke siklus 1 sebesar $13 \%$ atau sebanyak 20 siswa. Begitu juga dari siklus 1 ke siklus 2 peningkatan mencapai $11 \%$, atau sebanyak 12 siswa, dimana rerata kelas pada siklus 2 sebesar 89\%. hal ini tergolong sangat baik.

Walaupun terjadi peningkatan hasil belajar dari pra siklus ke siklus 1, tetapi nilai hasil belajar yang diperoleh jika dirata-rata masih dibawah nilai KKM, sehingga belum dapat dinyatakan tuntas secara klasikal. Jika pada siklus 1 hasil belajar siswa masih dibawah ketuntasan minimal $=75$, maka peneliti melanjutkan pada tahapan siklus 2 hingga mendapatkan ketuntasan secara klasikal atau hasil belajar mencapai nilai ketuntasan minimal.

Ada dua faktor yang mempengaruhi proses dan hasil belajar dari siswa, yaitu faktor internal dan faktor eksternal (Suparno, 2000:42 dalam Febriyanto 2010:40). Faktor internal berasal dari diri siswa itu sendiri, yaitu kurangnya kemampuan berkonsentrasi dan mengatur waktu. Sedangkan faktor ekternal bisa berasal dari lingkungan baik berupa fisik, sosial dan ekonomi. Berdasarkan hasil refleksi pada siklus I, faktor internal siswa yang mempengaruhi hasil belajar adalah kurangnya motivasi, kurangnya konsentrasi dan pengaturan waktu dari siswa itu sendiri. Sedangkan untuk faktor eksternal adalah kurangnya variasi guru dalam menyampaikan materi pelajaran di dalam kelas yang selama ini sering menggunakan metode ceramah dan sesekali menggunakan diskusi. Faktor - faktor inilah yang mempengaruhi hasil belajar siswa.

Keadaan kelas pada siklus II lebih aktif jika dibandingkan dengan siklus 1 dan kondisi kelas sudah sangat kondusif dan terjadi dan kenaikan yang signifikan, hal ini dapat diketahui dari siswa yang mendapatkan kreteria sangat baik dan 
baik, secara berurutan katagori sangat baik dan baik sebanyak 69\% (25 siswa) dan $28 \%$ (10 siswa). Sehingga peningkatan hasil belajar secara klasikal sebesar $86,11 \%$ (31 siswa yang tuntas) dengan nilai rata-rata 79,83= 80 dan diperoleh nilai tertinggi 98 sedangkan nilai terendah 68. Peningkatan ini dipengaruhi oleh keadaan siswa yang dapat langsung melihat letak dan bentuk struktur sel dengan komponen organel penyusun sel dari pembuatan model sel 3D, sehingga pengetahuan, pemahaman dan penafsiran tentang konsep struktur dan fungsi kmponen organel - organel sel lebih lekat dalam proses berpikir siswa. Selain itu siswa sudah mulai terbiasa dan tertarik dengan metode pembelajaran yang diterapkan. Dapat disimpulkan bahwa, penerapan metode CTL (Contekxstual Teaching And Learning) pada pembelajaran biologi pada pokok bahasan struktur dan fungsi sel dapat meningkatkan motivasi dan hasil belajar siswa kelas XI IPA.1 SMAN Jenggawah.

\section{KESIMPULAN DAN SARAN}

Berdasarkan hasil penelitian dan mengevaluasi, maka dapat ditarik kesimpulan sebagai berikut: (1) bahwa penerapan metode CTL (Contekxstual Teaching And Learning) dapat meningkatkan hasil belajar siswa, (2) penerapan metode CTL (Contekxstual Teaching And Learning) dapat meningkatkan motivasi hasil belajar siswa.

Dengan diketahuinya hasil penelitian yang telah dipaparkan sebelumnya maka disarankan kepada sesama rekan guru hendaknya selalu melakukan inovasi dalam pembelajaran untuk meningkatkan motivasi dan hasil belajar siswa. "Penerapan metode CTL (Contekxstual Teaching And Learning) " ini bisa dijadikan sebagai metode alternatif yang bisa digunakan.

\section{DAFTAR PUSTAKA}

Arikunto, Suharsimi. Suhardjono dan Supardi. 2006. Penelitian Tindakan Kelas. Jakarta : Bumi Aksara.

Chang. W. 2014. Metodologi Penulisan Ilmiah. Teknik Penulisan Esai, Skripsi, Tesis dan Disertasi. Jakarta : Erlangga. 
Chotimah, Husnul dan Dwitasari, Yuyun. 2009. Strategi-strategi Pembelajaran untuk Penelitian Tindakan Kelas. Malang: Surya Pena Gemilang.

Barwood, T. 2011. Strategi Belajar. Jakarta : Esensia Erlangga

Basith, A. 2011. Pengaruh Pembelajaran Konstektual Berbasis ICT dengan Strategi Inkuiri pada Materi Monera Terhadap Motivasi dan Hasil Belajar Siswa Kelas X SMAN 1 Bangil Pasuruan.Universitas Negeri Malang ( Tesis ).

Dahar. W. R. 2011. Teori - teori Belajar dan Pembelajaran. Jakarta : Erlangga.

Dimyati dan Mujiono. 1999. Belajar dan Pembelajaran. Jakarta: Rineka Cipta.

Fictor, Ferdinand \& Aribowo, Mukti. 2009. Praktis Belajar Biologi: Untuk Kelas XI Sekolah Menengah Atas/Madrasah Aliyah Program Ilmu Pengetahuan Alam. Jakarta. Pusat Penerbitan Buku Departemen Pendidikan Nasional.

Johnson, Elain B. 2009. Contextual Teacing and Learning. Bandung : MLC.

Masyud, M. Sulton. 2012. Analisis Data Statistik Untuk Penelitian Pendidikan. Edisi ke 3, cetakan ke 1, 2 dan 3. Jember. Lembaga Pengembangan Manajemen dan Profesi Kependidikan (LPMPK).

Masyud, M. Sulton. 2014. Publikasi Ilmiah Dalam Rangka PKB Guru. Edisi ke 2, cetakan ke 1 dan 2. Jember. Lembaga Pengembangan Manajemen dan Profesi Kependidikan (LPMPK).

Meier, D. 2002. The Accelerated Learning Hand Book. Bandung : Kaifa 
Nugraha, Satria. 2013. Penerapan Metode CTL (Contextual Teaching and Learning) Dalam Upaya Meningkatkan Prestasi Belajar Siswa Pada Materi Alat Peredaran Darah Manusia Di Kelas V SD Negeri 3 Cileduglor Kec. Ciledug Kab. Cirebon

Uno, H. B. 2010. Model Pembelajaran. Jakarta: Bumi Aksara.

Sardiman, A.M. 2005. Interaksi dan Proses Belajar Mengajar. Jakarta: PT Raja Grafindo Persada.

Setyosari, P. 2013. Metode Penelitian Pendidikan dan Pengembangan. Jakarta : Kencana Prenadamedia Group

Slameto. 2003. Belajar dan Faktor-faktor yang Mempengaruhinya. Jakarta : Rineka Cipta.

Sudjana, N. 2010. Penilaian Hasil Proses Belajar Mengajar. Bandung: PT Remaja Rosdakarya.

Silberman. H. L. 2006. Active Learning 101 Cara Belajar Siswa Aktif. Edisi Revisi. Bandung : Nusamedias.

Sumiati dan Asra. 2007. Metode Pembelajaran. Bandung : CV Wacana Prima.

Sutikno. M. S. 2014 Metode dan Model-model Pembelajaran Menjadi Proses Pembelajaran Lebih Variatif, Aktif, Inovatif, Efektif, dan Menyenangkan. Lombok : Holistica.

Suyanto dan Jihad, A. Menjadi Guru Profesional, Strategi Meningkatkan Kualifikasi dan Kualitas Guru di Era Global. Jakarta : Erlangga. 
Tampubolon, S. 2013. Penelitian Tindakan Kelas sebagai Pengembangan Profesi Pendidik dan Keilmuan. Jakarta : Erlangga

Trianto. 2007 : Model - model Pembelajaran Inovatif Berorientasi Konstruktivistik. Jakarta : Prestasi Pustaka Publisher. 